\title{
МЕТОДОЛОГИЧЕСКИЙ ПОДХОД К АНАЛИТИЧЕСКОЙ ДИАГНОСТИКЕ ОСТРЫХ ОТРАВЛЕНИЙ НЕКОТОРЫМИ НЕЙРОЛЕПТИКАМИ
}

\author{
И.П. Ремезова', А.С. Анацкая', Д.Ю. Санжиева', Н.Д. Бунятян ${ }^{2,3}$
}

${ }^{1}$ Пятигорский медико-фармацевтический институт - филиал ФГБОУ ВО ВолгГМУ

Минздрава России, 357500, Россия, г. Пятигорск, пр. Калинина, 11.

2ФГБУ «Научный центр экспертизы средств медицинского применения»

Минздрава России, 127051, Москва, Петровский бульвар, 8.

ЗФГАОУ ВО Первый Московский государственный медицинский университет

им. И.М. Сеченова Министерства здравоохранения Российской Федерации (Сеченовский университет), 119991, Россия, г. Москва, ул. Большая Пироговская, дом 2, стр. 4

DOI: 10.19163/MedChemRussia2021-2021-197

E-mail: i.p.remezova@pmedpharm.ru, ndbun@mail.ru

По данным Европейского регионального Бюро ВОЗ на долю психических расстройств выпадает 19,5\% всех лет жизни, утраченных в результате инвалидности [1]. Современные зарубежные тенденции в фармакокинетике и терапевтического лекарственного мониторинга показывают введение быстрых аналитических методов для одновременного количественного анализа нескольких препаратов и их метаболитов с целью предотвращения отравлений [2, 3].

Предложены методики изолирования, обнаружения и количественного определения клозапина, рисперидона, сертиндола, оланзапина, арипипразола, алимемазина, флупентиксола в случае ненаправленного и направленного анализа. С целью замены плазмы как объекта исследования на слюну для терапевтического мониторинга и химико-токсикологических анализов, а также сопоставимости полученных данных с учетом влияния эндогенных веществ слюны и плазмы на результаты анализа нами были рассчитаны коэффициенты корреляции. Предложена формула пересчета концентраций нейролептиков при замене плазмы крови на слюну. Для экспресс-диагностики отравлений разработаны методики анализа в моче изучаемых веществ.

\section{Литература}

1. Доклад о состоянии здравоохранения в Европе, 2018 г. Целевые ориентиры и более широкая перспектива - новые рубежи в работе с фактическими данными [Электронный ресурс] - Копенгаген: Европейское региональное бюро ВО3, 2018. Режим доступа: http://www.euro.who.int/ru/data-and-evidence/european-healthreport 2018.

2. Изотов Б.Н., Козлов А.А., Клименко Т.В., Бондарь И.В., Носфырев А.Е. Создание системы химико-токсикологического контроля немедицинского потребления наркотических средств и психотропных веществ на основе современных методов физикохимического анализа. Часть 1/ [и др.]//Наркология. 2009. №7. С. 61-69.

3. Wang B., Dearring C.L., Wager-Miller J., Mackie K. Drug detection and quantification directly from tissue using novel ionization methods for mass spectrometry [Электронный pecypc] / Eur. J. mass. spectrom. 2015. №21(3). Режим доступа: http://www.ncbi.nlm.nih. gov/pubmed/26307700. 